\title{
Some kinetics aspects of chlorine-solids reactions ${ }^{(\cdot)}$
}

\author{
N. Kanari*, D. Mishra**, J. Mochón***, L.F. Verdeja****, F. Diot* and E. Allain*
}

\begin{abstract}
The present paper describes detailed kinetics investigations on some selected chlorine-solid reactions through thermogravimetric measurements. The solids studied in this article include chemical pure oxides and sulfides as well as their natural bearing materials. The chlorinating agents employed are gaseous mixtures of $\mathrm{Cl}_{2}+\mathrm{N}_{2}$ (chlorination), $\mathrm{Cl}_{2}+\mathrm{O}_{2}$ (oxychlorination), and $\mathrm{Cl}_{2}+\mathrm{CO}$ (carbochlorination). Results are presented as effects of various parameters on the reaction rate of these solids with these chlorinating agents. It was observed that the reactivity of these solids towards different chlorinating agents varied widely. Sulfides could be chlorinated at room temperature, while carbochlorination of chromium (III) oxide was possible only above $500^{\circ} \mathrm{C}$. The variation of the chlorination rate of these complex materials with respect to gas velocity, composition and temperature enabled us to focus some light on the plausible reaction mechanisms and stoichiometries. The obtained results were used for selective removal of iron from chromite concentrates, extraction of valuable metals from sulfide materials, purification of $\mathrm{MgO}$ samples, etc.
\end{abstract}

Keywords

Thermogravimetric analysis; Complex oxides; Sulfides; Chlorination; Oxychlorination; Carbochlorination; Kinetics.

\section{Algunos aspectos cinéticos de las reacciones de sólidos con cloro}

\begin{abstract}
Resumen
Este trabajo describe detalladas investigaciones cinéticas en algunas reacciones seleccionadas de cloro-sólido a través de medidas termogravimétricas. Los sólidos estudiados en este artículo incluyen óxidos químicos puros y sulfuros, así como sus materiales naturales de soporte. Los agentes de cloración empleados son mezclas de gases de $\mathrm{Cl}_{2}+\mathrm{N}_{2}$ (cloración), $\mathrm{Cl}_{2}+\mathrm{O}_{2}$ (oxicloración) y $\mathrm{Cl}_{2}+\mathrm{CO}$ (carbocloración). Los resultados se presentan como efecto de varios parámetros en el porcentaje de reacción de estos sólidos con los agentes de cloración. Se ha observado que la reactividad de estos sólidos a través de diferentes agentes de cloración varía ampliamente. Los sulfuros se pudieron clorar a temperatura ambiente mientras que la carbocloración del óxido de cromo (III) sólo fue posible por encima de los $500^{\circ} \mathrm{C}$. La variación del porcentaje de cloración de estos materiales complejos con respecto a la velocidad del gas, composición y temperatura permitió arrojar alguna luz en los posibles mecanismos de reacción y estequiometrías. Los resultados obtenidos se han usado para la eliminación selectiva del hierro de concentrados de cromo, extracción de metales valiosos de materiales sulfhídricos, purificación de muestras de $\mathrm{MgO}$, etc.
\end{abstract}

Palabras clave Análisis termogravimétrico; Óxidos complejos; sulfuros; Cloración; Oxicloración; Carbocloración; Cinética.

\section{INTRODUCTION}

It is well known that chlorine possesses a high reactivity towards different substances at low temperatures. Further, many metal chlorides and/or oxychlorides have low boiling points and also have appreciably different vapor pressures at a particular temperature. These aspects led the "chlorine technique" as the subject of much attention in areas like mineral beneficiation, metal extraction and waste treatment. Many important articles devoted to the chlorination can be found in the literature ${ }^{[1]}$. The present paper mainly focuses on the kinetics aspects of chlorine-solids reactions approached through thermogravimetric measurements. Besides, higher selectivity of the chlorination methods by

\footnotetext{
(•) Trabajo recibido el día 4 de diciembre de 2008 y aceptado en su forma final el día 3 de julio de 2009.

* Laboratoire Environnement et Minéralurgie, UMR 7569 CNRS, Nancy-University, ENSG, BP 40, 54501 Vandoeuvre-lès-Nancy Cedex, France.

e-mail: ndue.kanari@ensg.inpl-nancy.fr

${ }^{* *}$ National Metallurgical Laboratory (NML), Jamshedpur, India - 831007.

*** CENIM - CSIC, Av. Gregorio del Amo 8. Madrid 28040, Spain.

${ }^{\star * * \star}$ E.T.S.I. de Minas de Oviedo, Cátedra de Siderurgia, Independencia s/n. Oviedo 33004, Spain.
} 
employing different chlorinating medium such as oxychlorination $\left(\mathrm{Cl}_{2}+\mathrm{O}_{2}\right)$ or carbochlorination $\left(\mathrm{Cl}_{2}+\mathrm{CO}\right)$ is also discussed. Below paragraphs depict some examples where detailed kinetic studies were made.

The first example presents how $\mathrm{Cl}_{2}$ can be used at low temperature for extraction of non-ferrous metals from sulfide concentrates $\left(\mathrm{CuFeS}_{2}, \mathrm{PbS}, \mathrm{ZnS}\right.$, $\mathrm{FeS}_{2}$, etc.). It was observed that these sulfides interact with chlorine even at room temperature ${ }^{[2-4]}$. At about $300^{\circ} \mathrm{C}$, generated iron and sulfur chlorides were volatilized whilst the valuable metal chlorides $\left(\mathrm{CuCl}_{2}\right.$, $\mathrm{PbCl}_{2}$, and $\mathrm{ZnCl}_{2}$ ) were essentially concentrated in the chlorination residues. More than $95 \%$ of copper contained in the concentrate was recovered in the residue at $300{ }^{\circ} \mathrm{C}$ as water soluble $\mathrm{CuCl}_{2}$.

The second case study presented is the upgrade of lean chromite ores and/or concentrate. It may be mentioned that, physical beneficiation of this material is almost impossible. Chlorination of chromite was carried out in presence of a reducing agent (for example CO). Results obtained earlier ${ }^{[2}$ y 5$]$ indicated that the carbochlorination $\left(\mathrm{Cl}_{2}+\mathrm{CO}\right)$ of this material at about $550^{\circ} \mathrm{C}$ led to preferential extraction of iron. The chlorination extent of chromium was negligible and the $\mathrm{Cr} / \mathrm{Fe}$ ratio was almost doubled in the residues, compared with that of the raw sample. Carbochlorination at higher temperatures led to a total extraction of chromite elements as chlorides $\left(\mathrm{CrCl}_{3}, \mathrm{FeCl}_{3}, \mathrm{AlCl}_{3}\right.$, and $\left.\mathrm{MgCl}_{2}\right)$. A selective condensation of the gaseous phase allowed the recovery of almost pure $\mathrm{MgCl}_{2}$. Similarly, the chromium chloride was separated from those of iron and aluminum.

The third example presents the selectivity of chlorination reaction in the presence of oxygen. This approach was used for the selective chlorination of elements contained in the chromite ${ }^{[2,6 \text { y } 7]}$ and for purification of magnesium oxide through selective chlorination and removal of iron oxides ${ }^{[8]}$.

In order to have better understanding of the chlorination $\left(\mathrm{Cl}_{2}\right)$, carbochlorination $\left(\mathrm{Cl}_{2}+\mathrm{CO}\right)$ and oxychlorination $\left(\mathrm{Cl}_{2}+\mathrm{O}_{2}\right)$ behavior of various raw materials, and detailed kinetic studies of these solids with various chlorinating gas mixtures were undertaken. The main objective of this article is to demonstrate the usefulness of simple thermogravimetric analyses (TGA) methods for effective measurement of chlorination kinetics of above mentioned selected solid samples with various chlorinating gas mixtures. The obtained kinetic information can be subsequently used for the upgrade of lean ores, such as chromites, complex sulfides, etc., and/or extraction of several valuable metals such as $\mathrm{Cu}, \mathrm{Mg}, \mathrm{Pb}$ etc.

\section{METHODOLOGY OF THE KINETICS STUDY}

The methodology adopted for the kinetics studies of various solid samples with different chlorinating gaseous mixtures consists in the following:

1. thermogravimetric analysis (TGA) using nonisothermal conditions,

2. batch-boat experiments and analysis of the solid products (SEM, microprobe, XRD, chemical analysis, etc.),

3. comparison of the reaction rate with that of volatilization of the reaction products,

4. determination of adequate gaseous mixture flow rate,

5. effect of the reactive gases proportions on the reaction rate,

6. determination of the apparent reaction orders with respect to the reactive gases,

7. evaluation of the apparent activation energy of the reaction (effect of temperature),

8. mathematical data processing in order to define the geometry of the reaction interface

9. indication of the possible rate controlling step.

Detailed results of the chlorination kinetics of different solids were reported in literature ${ }^{[2-10]}$. Only some typical examples will be described illustrating the stages of these kinetics studies. The materials and experimental procedure are briefly depicted in the next section. However, more accurate conditions for each kinetics example will be given during the development of each individual kinetic study.

\section{MATERIALS AND EXPERIMENTAL PROCEDURE}

The sulfides' samples used in this investigation were the chalcopyrite $\left(\mathrm{CuFeS}_{2}\right)$, pyrite $\left(\mathrm{FeS}_{2}\right)$, galena $(\mathrm{PbS})$ and sphalerite $(\mathrm{ZnS})$. The elemental and mineralogical compositions of these samples of natural origin were determined by Scanning Electron Microscopy (SEM) and X-ray diffraction (XRD) analyses. Besides, a high grade copper concentrate "HGCC" was also used. It contains about $81.7 \%$ $\mathrm{CuFeS}_{2}, 6.4 \% \mathrm{ZnS}, 5.7$ \% lead compounds, $3.0 \%$ iron sulfides and less than $1.0 \% \mathrm{SiO}_{2}$. The oxides' samples of chromium $\left(\mathrm{Cr}_{2} \mathrm{O}_{3}\right)$, iron $\left(\mathrm{Fe}_{2} \mathrm{O}_{3}\right)$ and magnesium $(\mathrm{MgO})$ were supplied by PROLABO (Paris, France). They are of synthetic origin and have a purity as high as $99 \%$. The chromite sample used for this study was obtained from a chromite concentrate by successive separations in dense liquor in order to separate the gangue from the chromite 
mineral. Results of the microprobe and classical chemical analysis suggest that the chromite sample could be represented as: $\left(\mathrm{Fe}^{2+}{ }_{0.30}, \mathrm{Mg}_{0.70}\right)\left(\mathrm{Cr}_{1.56}\right.$, $\left.\mathrm{Al}_{0.37}, \mathrm{Fe}^{3+}{ }_{0.07}\right) \mathrm{O}_{4}$. All used samples were in powder state with low specific surface areas indicating a week grains' porosity.

The thermogravimetric analysis (TGA) were performed using a micro-electronic balance CAHN type $\mathrm{C} 1000$. The accuracy of this type of apparatus is about $0.1 \%$ for a sensitivity of $0.5 \mu \mathrm{g}$. The $\left(\mathrm{Cl}_{2}\right.$, $\mathrm{CO}, \mathrm{O}_{2}, \mathrm{~N}_{2}$ ) gas flows are measured separately. They can be mixed and homogenized. Almost all the residual moisture of these gases is eliminated by circulation through $\mathrm{CaCl}_{2}$ columns. The gas inlet system is built so that the gases are preheated before reacting with the sample. The temperature and the weight of the sample are recorded continuously as a function of time by a data acquisition system.

The thermogravimetric analysis is run using continuous temperature raise or isotherm modes. The experimental protocol was the following:

1. an amount of sample of about $40 \mathrm{mg}$ was scattered uniformly in a large quartz nacelle,

2. during the non isothermal treatment, the pure gases or gas mixtures $\left(\mathrm{Cl}_{2}, \mathrm{CO}, \mathrm{Cl}_{2}+\mathrm{N}_{2}\right.$ $\mathrm{Cl}_{2}+\mathrm{CO}, \mathrm{Cl}_{2}+\mathrm{CO}+\mathrm{N}_{2}, \mathrm{Cl}_{2}+\mathrm{O}_{2}$ and/or $\mathrm{Cl}_{2}+\mathrm{O}_{2}+\mathrm{N}_{2}$ ) were flown through the reactor and at the same time the furnace power was switched on,

3. for the isotherm mode experiment the sample was preheated in a low nitrogen flow up to the desired temperature, this before flowing the reactive gases through the reactor,

4. at the end of the predetermined treatment time, the reactive gases were replaced by nitrogen and the furnace is lowered down, and the reactor cools down as a result of $\mathrm{N}_{2}$ flow,

5. the nacelle was taken out from the reactor and weighted. The treatment product was set aside for different analyses.

Few batch-boat chlorination tests were also performed in a horizontal experimental set-up. This set-up was composed of a gas metering unit followed by a gas purification system and a horizontal furnace. The gaseous reaction products were recovered through condensers and the outlet gases were purified before their release to the atmosphere. The reaction products (chlorination residues as well as condensates) were examined by SEM, XRD and chemical analyses.

Data obtained from different treatments were initially plotted as evolution of $\%$ weight change as a function of time. All negative values represent \% weight losses ( $\% \mathrm{WL})$, whilst positive ones express the $\%$ weight gains.

\section{RESULTS AND DISCUSSION}

\subsection{Thermogravimetric analysis using non-isothermal conditions}

These experiments could give preliminary information on the temperature range for the kinetic studies. In other words, TGA allows rapidly the evaluation of the reactivity of various solids towards chlorinating gas mixtures. For example, in figure 1 the percentage weight change of several sulfides with respect to temperature during their chlorination with $\mathrm{Cl}_{2}+\mathrm{N}_{2}$ gas mixture under non-isothermal conditions with a heating rate $(\mathrm{dT} / \mathrm{dt})$ of about $20^{\circ} \mathrm{C} / \mathrm{min}$ are presented.

Several important information are obtained from this figure such as: chalcopyrite starts to react with chlorine even at room temperature, at higher temperature this reaction leads to the formation of cupric, ferric, and sulfur chlorides as final reaction products ${ }^{[2]}$; for pyrite initial weight gain was observed due to the substitution of sulfur by chlorine, while the weight losses of this sample at temperature higher than $250^{\circ} \mathrm{C}$ were attributed to the volatilization of ferric chloride; sphalerite and the galena started to react with chlorine at temperatures higher than $200^{\circ} \mathrm{C}$ generating their respective chlorides. Full reaction and volatilization of the chlorination products of the studied sulfides took place at higher temperatures.

However, the chlorination of sulfides is very complex and is difficult to be explained only by their treatment in non isothermal conditions. In order to have an insight about the pure sulfides' chlorination, a series of batch-boat tests was performed between room temperature and $750{ }^{\circ} \mathrm{C}$ for a reaction time of $2 \mathrm{~h}$. Results were drawn as

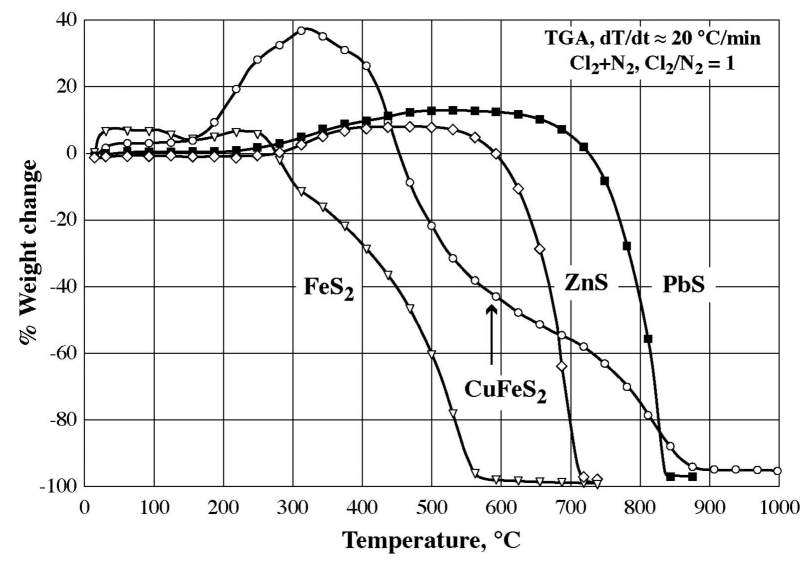

Figure 1. TGA of several sulfides in $\mathrm{Cl}_{2}+\mathrm{N}_{2}$. Figura 1. ATG de algunos sulfuros en atmósfera de $\mathrm{Cl}_{2}+\mathrm{N}_{2}$. 
evolution of weight change as function of the temperature in figure 2. A high grade copper concentrate "HGCC" composed essentially of chalcopyrite was also treated in same conditions. The chlorination residues and condensates were systematically analyzed by SEM and XRD analysis. The chlorination residues of HGCC were subjected to chemical analysis for copper and iron contents.

The presence of chlorine, as observed by SEM, in the chlorination residue obtained at room temperature for $\mathrm{CuFeS}_{2}, \mathrm{FeS}_{2}$ and $\mathrm{HGCC}$ indicates that chlorine had reacted with these sulfides. The peak intensity of sulfur decreased with the temperature rise, while that of chlorine increased. At $300^{\circ} \mathrm{C}$, SEM analysis showed that the residues obtained from chlorination $\mathrm{CuFeS}_{2}$ and $\mathrm{HGCC}$ were sulfur-free indicating that full chlorination of the sulfides was achieved. XRD results showed the presence of $\mathrm{CuCl}_{2}$, besides non reacted $\mathrm{CuFeS}_{2}$, in the chlorination residue of chalcopyrite and HGCC samples from room temperature.

Condensates of chlorination of $\mathrm{FeS}_{2}, \mathrm{CuFeS}_{2}$ and $\mathrm{HGCC}$ were significantly observed at temperatures higher than $200^{\circ} \mathrm{C}$. These condensates were essentially composed of $\mathrm{Fe}$ and $\mathrm{Cl}$ for a chlorination temperature lower than $300{ }^{\circ} \mathrm{C}$ showing that iron was removed as $\mathrm{FeCl}_{3}$ which is characterized by a vapor pressure of about $1 \mathrm{~atm}$ at temperatures close to $300^{\circ} \mathrm{C}$ (Fig. 3). At temperatures equal and higher than $400^{\circ} \mathrm{C}$, copper

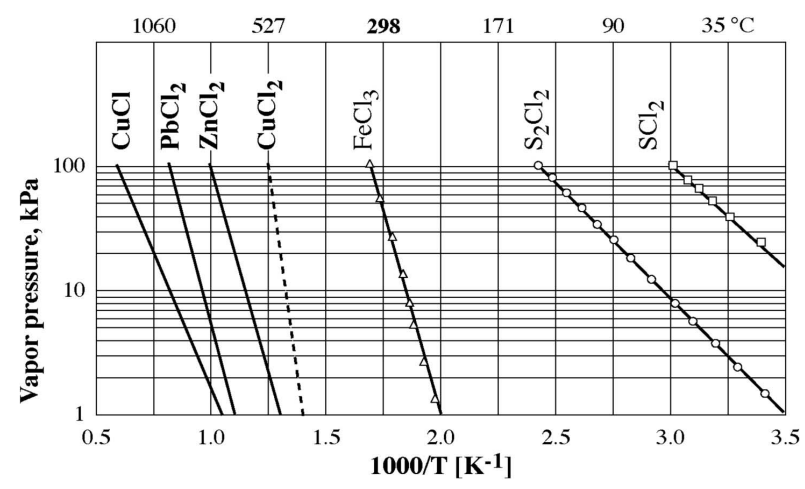

Figure 3. Evolution of vapor pressure of several chlorides versus inverse of temperature.

Figura 3. Evolución de la presión de vapor de algunos cloruros frente al inverso de la temperatura.

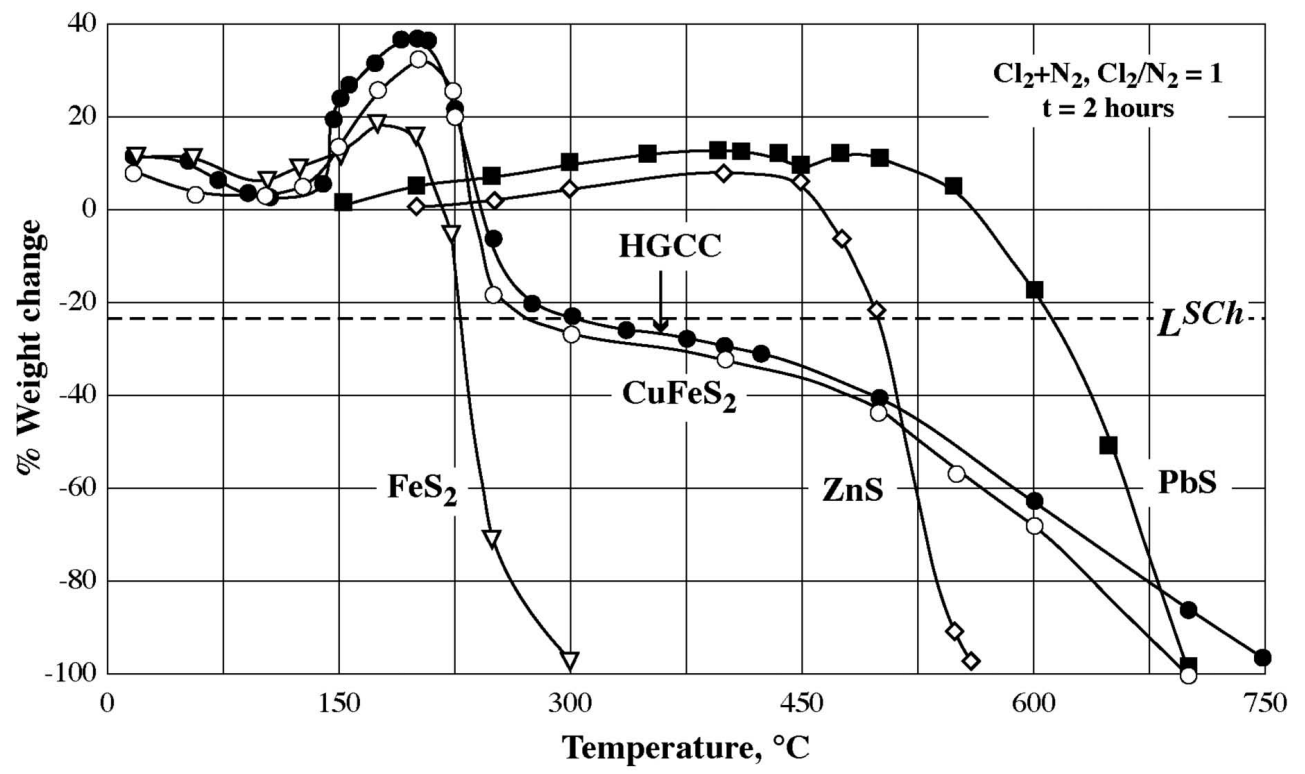

\begin{abstract}
LSCh: Theoretical limit for de selective chlorination of HGCC (high grade copper concentrate) supposing full chlorination of sulphides and volatilization of iron and sulphur chlorinated.

LSCh: Límite teórico de la cloruración selectiva de un concentrado de calcopirita con alto contenido en cobre (HGCC) suponiendo una completa cloración de los sulfuros presentes y la volatilización de compuestos sulfurados de hierro y de otros elementos metálicos ( $\mathrm{FeS}_{2}, \mathrm{ZnS}$ y PbS) que han reaccionado con el cloro.
\end{abstract}

Figure 2. Evolution of \% weight change versus temperature during chlorination of several sulfides and a high grade copper concentrate ' $\mathrm{HGCC}$ ' in $\mathrm{Cl}_{2}+\mathrm{N}_{2}$ for $2 \mathrm{~h}$.

Figura 2. Evolución del \% de cambio de peso frente a la temperatura durante la cloración de varios sulfuros y un concentrado de cobre con un alto contenido de cobre en atmósfera de $\mathrm{Cl}_{2}+\mathrm{N}_{2}$ durante $2 \mathrm{~h}$. 
was also detected in the condensate of $\mathrm{CuFeS}_{2}$ and HGCC chlorination. Sulfur was not detected in the solid condensates regardless of the chlorination temperature, indicating that sulfur was essentially removed as $\mathrm{S}_{\mathrm{x}} \mathrm{Cl}_{\mathrm{y}}\left(\mathrm{S}_{2} \mathrm{Cl}_{2}+\mathrm{SCl}_{2}\right.$ and intermediates) which have sufficiently high vapor pressures (Fig. 3) to be transported out by the exhaust gases. The formation of sulfur dichloride is probably due to high partial pressure of chlorine in the chlorination process. The formation of cuprous chloride $(\mathrm{CuCl})$ during chlorination of $\mathrm{CuFeS}_{2}$ and $\mathrm{HGCC}$ was confirmed by $\mathrm{XRD}$ at temperature equal or higher than $600^{\circ} \mathrm{C}$. It is probably product of cupric chloride decomposition in spite of high partial pressure of chlorine.

The qualitative analyses such as SEM and XRD indicated that, in our conditions, the temperatures close to $300^{\circ} \mathrm{C}$ were adequate for the full chlorination of pyrite and chalcopyrite and for the volatilization of sulfur and iron chlorinated compounds. The chemical analysis of chlorination residue of HGCC showed that complete iron extraction was achieved at $300^{\circ} \mathrm{C}$ and all copper is concentrated in the residue. The theoretical limit of selective chlorination of HGCC ( $\mathrm{L}^{\mathrm{SCh}}$ in figure 2) is fully consistent with \% WL of sample and extraction extent of iron obtained at $300{ }^{\circ} \mathrm{C}$. The copper extraction started at higher and about 40 pct of copper were extracted at $600^{\circ} \mathrm{C}$.

The sulfides of zinc and lead reacted with chlorine at temperatures equal to or higher than $150^{\circ} \mathrm{C}$ leading to their respective chlorides. However, complete reaction of $\mathrm{ZnS}$ was achieved at temperature lower than that of $\mathrm{PbS}$. The chlorination of these sulfides is also complicated by the formation of liquid phases (M.p. of $\mathrm{ZnCl}_{2}$ is $283^{\circ} \mathrm{C}$ ) and/or formation of an eutectic at $450^{\circ} \mathrm{C}$ in the $\mathrm{PbS}-\mathrm{PbCl}_{2}$ system.

The complete chlorination of the selected sulfides can be classified by following descending order $\mathrm{FeS}_{2}$ $>\mathrm{CuFeS}_{2}>\mathrm{ZnS}>\mathrm{PbS}$. It seems that this sequence follows the evolution of vapor pressure of chlorides as shown by figure 3. Nevertheless, other phenomena could occur during chlorination of sulfide at high temperatures such as decomposition of chalcopyrite and pyrite to cubanite and pyrrhotite, respectively and/or volatilization of lead sulfide.

Pertinently to these results, the chlorination kinetics of these sulfides at temperature $\leq 300^{\circ} \mathrm{C}$ were studied in details in former works ${ }^{[2-4]}$.

\subsection{Comparison of the reaction rate with that of volatilization of the reaction products}

The reactions of chlorine with a solid generate chlorides which have particular vapor pressure at a given temperature. Consequently, temperature plays a crucial role in kinetic measurements, which defines the proportion of chlorides that volatilized to that of which remains in the reaction zone (unvolatilized). Use of TGA technique to measure the evolution of the reaction extent require that either the volatilization rate of the reaction products is higher than that of its rate of formation or the chlorinated products remain completely in the reaction zone under the studied temperature range.

Figure 4 illustrates an example of $\mathrm{Cr}_{2} \mathrm{O}_{3}$ carbochlorination using non-isothermal ${ }^{[2-10]}$. The reaction of $\mathrm{Cr}_{2} \mathrm{O}_{3}$ with $\mathrm{Cl}_{2}+\mathrm{CO}$ can be described by equation (1).

$$
\begin{gathered}
1 / 3 \mathrm{Cr}_{2} \mathrm{O}_{3}+\mathrm{Cl}_{2}+\mathrm{CO} \rightarrow \\
2 / 3 \mathrm{CrCl}_{3}+\mathrm{CO}_{2}
\end{gathered}
$$

Assuming that chromium (III) chloride $\left(\mathrm{CrCl}_{3}\right)$ is the only chlorinated product of the reaction, the volatilization of $\mathrm{CrCl}_{3}$ was tested in the same gaseous mixture $\left(\mathrm{Cl}_{2}+\mathrm{CO}\right)$. Results are also depicted in figure 4. It is clear from this figure, that the rate of volatilization of $\mathrm{CrCl}_{3}$ at temperatures above $500^{\circ} \mathrm{C}$ is higher than its rate of formation through the reaction of $\mathrm{Cr}_{2} \mathrm{O}_{3}$ with $\mathrm{Cl}_{2}+\mathrm{CO}$. In these conditions, the observed weight loss of $\mathrm{Cr}_{2} \mathrm{O}_{3}$ reaction with $\mathrm{Cl}_{2}+\mathrm{CO}$ could be a direct measure of the extent of $\mathrm{Cr}_{2} \mathrm{O}_{3}$ carbochlorination reaction.

The chlorination of the magnesium oxide represents another case study. The reaction of $\mathrm{MgO}$ with chlorine (Eq. (2)), in absence of a reducing atmosphere, takes

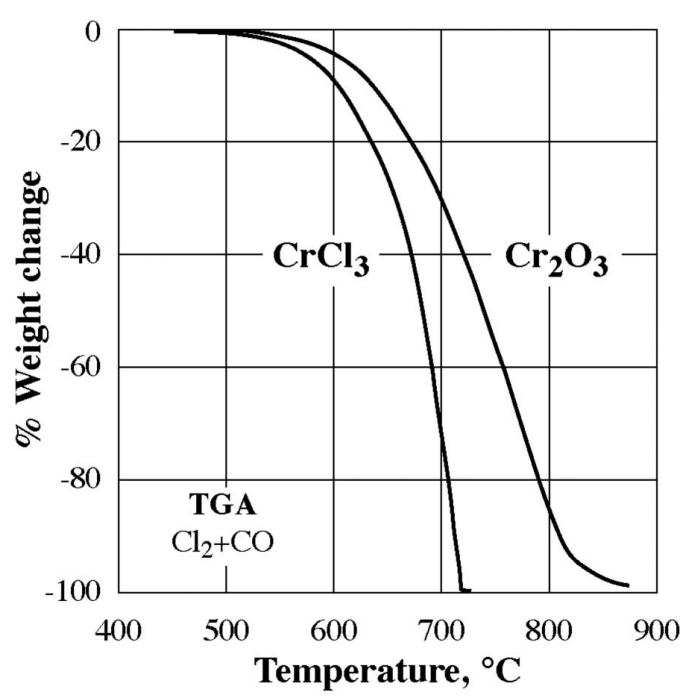

Figure 4. TGA of $\mathrm{Cr}_{2} \mathrm{O}_{3}$ and $\mathrm{CrCl}_{3}$ in $\mathrm{Cl}_{2}+\mathrm{CO}$.

Figura 4. ATG del $\mathrm{Cr}_{2} \mathrm{O}_{3}$ y $\mathrm{CrCl}_{3}$ en atmósfera de $\mathrm{Cl}_{2}+\mathrm{CO}$. 
place at $\mathrm{T}>600^{\circ} \mathrm{C}{ }^{[2-10]}$. Magnesium chloride has melting and boiling points of $714^{\circ} \mathrm{C}$ and $1,412^{\circ} \mathrm{C}$, respectively. One possible way to decrease the reaction rate of $\mathrm{MgO}$ with chlorine is to increase the partial pressure of oxygen in the system. This can lead to a volatilization rate of $\mathrm{MgCl}_{2}$, obtained according equation (2), higher than that of its formation.

$$
\mathrm{MgO}+\mathrm{Cl}_{2} \rightarrow \mathrm{MgCl}_{2}+1 / 2 \mathrm{O}_{2}
$$

A series of $\mathrm{MgO}$ chlorination tests was performed at $950^{\circ} \mathrm{C}$, using a $\mathrm{Cl}_{2}+\mathrm{O}_{2}$ gas mixture with an oxygen content that varied from 0 to $66.7 \%$ (molar \%). Figure 5 shows the evolution of \% weight change of $\mathrm{MgO}$ sample versus time during its oxychlorination for the conditions mentioned above. This figure suggests that the chlorinating gas mixtures containing more than $90 \%$ of $\mathrm{Cl}_{2}$ lead to a chlorination rate that is higher than that of $\mathrm{MgCl}_{2}$ volatilization. For this reason, the kinetics of $\mathrm{MgO}$ oxychlorination was studied using a $\mathrm{Cl}_{2}+\mathrm{O}_{2}$ gas mixture containing a chlorine content less than or equal to $80 \%{ }^{[8]}$. Then, the carbochlorination kinetics of $\mathrm{MgO}$ in $\mathrm{Cl}_{2}+\mathrm{CO}$ was investigated at temperatures lower than the melting point of $\mathrm{MgCl}_{2}{ }^{[10]}$ assuming that the $\mathrm{MgCl}_{2}$ volatilization is negligible.

\subsection{Determination of adequate gaseous mixture velocity}

In order to determine the intrinsic parameters of the gas-solid reaction, it is necessary to minimize the effect of external mass transfer phenomena. This can be

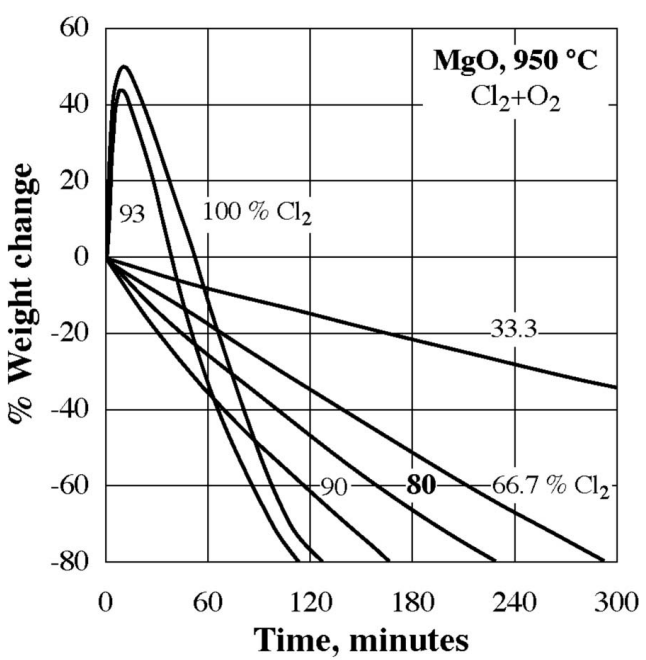

Figure 5. Evolution of \% weight change as function of time during isothermal treatment of $\mathrm{MgO}$ in $\mathrm{Cl}_{2}+\mathrm{O}_{2}$ at various chlorine contents.

Figura 5. Evolución del \% de cambio de peso como función del tiempo durante el tratamiento isotérmico de $\mathrm{MgO}$ en atmósfera de $\mathrm{Cl}_{2}+\mathrm{O}_{2}$ con diferentes contenidos de cloro.

achieved by using a high velocity of reactive gases such that the reaction rate becomes unaffected. As the mass transfer phenomena are promoted at high temperature, the effect of the gas velocity on the reaction rate of a chlorination reaction was studied at high temperature ${ }^{[2]}$ or at two different temperatures. The experimental results of the effect of $\mathrm{Cl}_{2}+\mathrm{O}_{2}$ velocity on the oxychlorination of $\mathrm{Fe}_{2} \mathrm{O}_{3}$ at $750^{\circ} \mathrm{C}$ and $950{ }^{\circ} \mathrm{C}$ are given in figure 6 . They indicate that the gas velocities
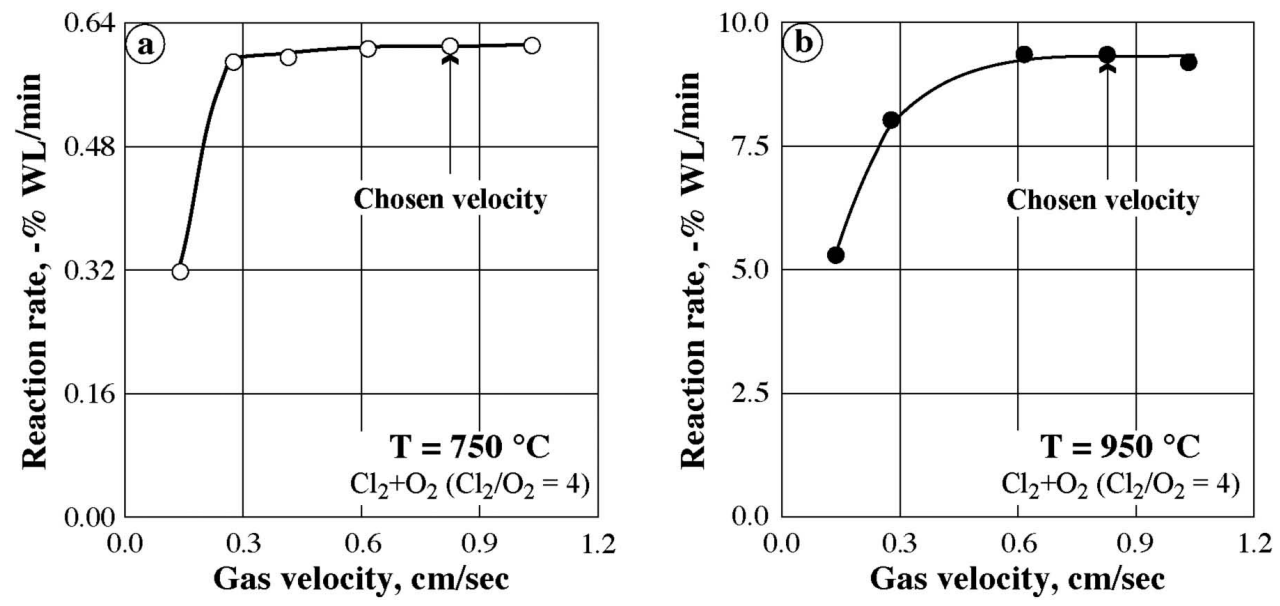

Figure 6. Oxychlorination rate of $\mathrm{Fe}_{2} \mathrm{O}_{3}$ versus gas velocity of $\mathrm{Cl}_{2}+\mathrm{O}_{2}$ at (a) $750{ }^{\circ} \mathrm{C}$ and (b) $950{ }^{\circ} \mathrm{C}$.

Figura 6. Tasa de la volatilización por oxicloración del $\mathrm{Fe}_{2} \mathrm{O}_{3}$ en relación a la velocidad de un fluido gaseoso de $\mathrm{Cl}_{2}+\mathrm{O}_{2}$ (a) $750^{\circ} \mathrm{C}$ y (b) $950^{\circ} \mathrm{C}$. 
higher than $0.6 \mathrm{~cm} / \mathrm{second}$ are sufficient to minimize the effect of external mass transfer at both chosen temperatures. Consequently, all kinetic parameters of hematite oxychlorination were investigated by using a gases velocity of about $0.83 \mathrm{~cm} / \mathrm{s}$.

\subsection{Effect of the reactive gases composition on the reaction rate}

The gaseous mixtures used in the chlorination studies were $\mathrm{Cl}_{2}+\mathrm{CO}, \mathrm{Cl}_{2}$, and $\mathrm{Cl}_{2}+\mathrm{O}_{2}$. As it could be expected, the rate of a chlorination reaction will be affected by the ratio of these gases in the chosen gaseous mixture.

The following examples demonstrate the effects of the $\mathrm{Cl}_{2} / \mathrm{CO}$ and $\mathrm{Cl}_{2} / \mathrm{O}_{2}$ ratios on the chlorination reaction rates of several oxides. Experimental results are summarized in figure 7 . The results of carbochlorination rate of $\mathrm{Cr}_{2} \mathrm{O}_{3}$ at $800^{\circ} \mathrm{C}$, as a function of $\mathrm{Cl}_{2} /\left(\mathrm{Cl}_{2}+\mathrm{CO}\right)$ molar ratio is shown in figure $7 \mathrm{a}$ ). The reaction rate of $\mathrm{Cr}_{2} \mathrm{O}_{3}$ with $100 \%$ $\mathrm{CO}$ is almost equal to zero and rises when the chlorine content in the gas mixture increases. It reaches a maximum value for a $\mathrm{Cl}_{2} /\left(\mathrm{Cl}_{2}+\mathrm{CO}\right)$ ratio of $\approx 0.5$. Beyond this ratio, the reaction rate decreases as the chlorine content increases and reaches a minimum
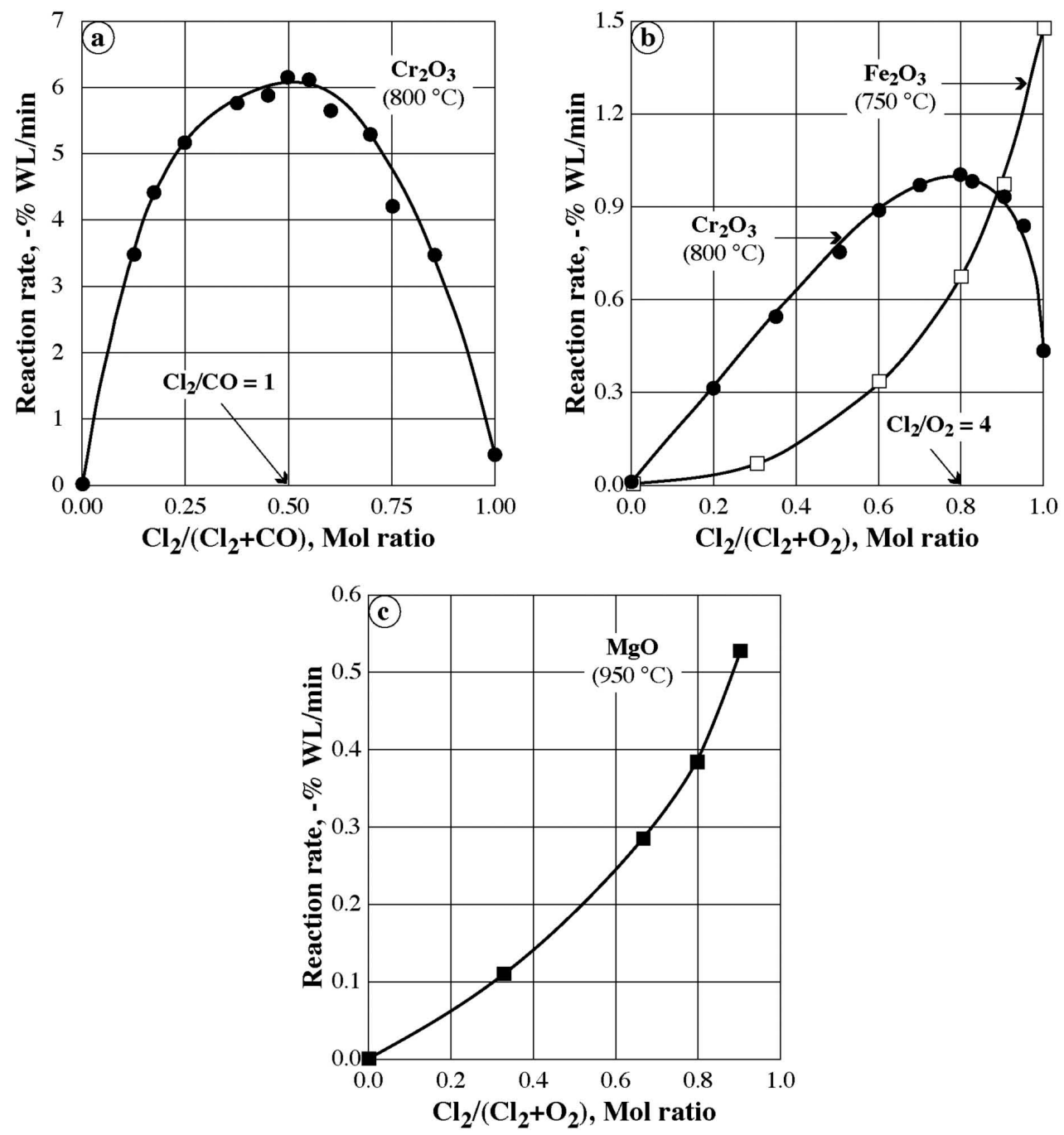

Figure 7. Evolution of the reaction rates as a function of the reactive gases ratios for: (a) carbochlorination of $\mathrm{Cr}_{2} \mathrm{O}_{3}$ at $800^{\circ} \mathrm{C}$; (b) oxychlorination of $\mathrm{Cr}_{2} \mathrm{O}_{3}$ at $800^{\circ} \mathrm{C}$ and $\mathrm{Fe}_{2} \mathrm{O}_{3}$ at $750{ }^{\circ} \mathrm{C}$ and (c) oxychlorination of $\mathrm{MgO}$ at $950{ }^{\circ} \mathrm{C}$.

Figura 7. Evolución de las tasas de reacción en función de cocientes de reacción de los gases para: (a) carbocloración de $\mathrm{Cr}_{2} \mathrm{O}_{3}$ a $800^{\circ} \mathrm{C}$; (b) oxicloración de $\mathrm{Cr}_{2} \mathrm{O}_{3}$ a $800^{\circ} \mathrm{C}$ y $\mathrm{Fe}_{2} \mathrm{O}_{3}$ a $750^{\circ} \mathrm{C}$ y (c) oxicloración de $\mathrm{MgO}$ a $950^{\circ} \mathrm{C}$. 
value with $100 \% \mathrm{Cl}_{2}$. The observed maximum reaction rate at $\mathrm{Cl}_{2} /\left(\mathrm{Cl}_{2}+\mathrm{CO}\right)$ ratio of 0.5 suggests that the carbochlorination of $\mathrm{Cr}_{2} \mathrm{O}_{3}$ with $\mathrm{Cl}_{2}+\mathrm{CO}$ follows equation (1). The effect of the $\mathrm{Cl}_{2} /\left(\mathrm{Cl}_{2}+\mathrm{O}_{2}\right)$ molar ratio on the oxychlorination of $\mathrm{Cr}_{2} \mathrm{O}_{3}$ at $800{ }^{\circ} \mathrm{C}$ is represented in figure $7 \mathrm{~b}$ ). The oxychlorination rates passes by a maximum corresponding to a $\mathrm{Cl}_{2} /\left(\mathrm{Cl}_{2}+\mathrm{O}_{2}\right)$ molar ratio of about 0.8. This value corresponds to a molar ratio of $\mathrm{Cl}_{2} / \mathrm{O}_{2}$ equal to 4 . These results show that chlorination of $\mathrm{Cr}_{2} \mathrm{O}_{3}$ with $\mathrm{Cl}_{2}+\mathrm{O}_{2}$ gas mixture takes place according to equation (3) involving the formation of chromium oxychloride as the main reaction product.

$$
1 / 2 \mathrm{Cr}_{2} \mathrm{O}_{3}+\mathrm{Cl}_{2}+1 / 4 \mathrm{O}_{2} \rightarrow \mathrm{CrO}_{2} \mathrm{Cl}_{2}
$$

As this could be expected, the oxychlorination rate of $\mathrm{Fe}_{2} \mathrm{O}_{3}$ (Fig. 7 b)) increases when the $\mathrm{Cl}_{2} /\left(\mathrm{Cl}_{2}+\mathrm{O}_{2}\right)$ molar ratio augments and it reaches a maximum value for the chlorination in absence of oxygen. Thus chlorination of $\mathrm{Fe}_{2} \mathrm{O}_{3}$ can be described by equation (4).

$$
1 / 3 \mathrm{Fe}_{2} \mathrm{O}_{3}+\mathrm{Cl}_{2} \rightarrow 2 / 3 \mathrm{FeCl}_{3}+1 / 2 \mathrm{O}_{2}
$$

Similarly, the reaction rate of $\mathrm{MgO}$ with $\mathrm{Cl}_{2}+\mathrm{O}_{2}$ (Fig. 7 c)) augments with the decrease of oxygen content in the $\mathrm{Cl}_{2}+\mathrm{O}_{2}$ gas mixture. This may be explained by the fact that the presence of oxygen in the gas mixture will shift the reaction of equation (2) to the left side.

\subsection{The apparent reaction orders with respect to the reactive gases}

\subsubsection{Apparent reaction orders with respect to $\mathrm{Cl}_{2}$ and $\mathrm{O}_{2}$}

To determine the apparent reaction order with respect to $\mathrm{Cl}_{2}$, a series of experimental tests were carried out at constant partial pressure of oxygen $(0.33 \mathrm{~atm})$ and the chlorine partial pressure was varied in a defined interval. Similarly, the apparent reaction order with respect to $\mathrm{O}_{2}$ was derived from the experimental results at constant $\mathrm{Cl}_{2}$ partial pressure $(0.33 \mathrm{~atm})$. In all cases, the chosen gas velocities correspond to optimal values defined previously. Nitrogen was used as a carrier gas.

\subsubsection{Apparent reaction order with respect to $\mathrm{Cl}_{2}+\mathrm{O}_{2}$}

A gas mixture of $\mathrm{Cl}_{2}+\mathrm{O}_{2}+\mathrm{N}_{2}$ with a velocity of 0.55 $\mathrm{cm} / \mathrm{second}$ was used. The $\mathrm{Cl}_{2} / \mathrm{O}_{2}$ molar ratio of the gas mixture was kept constant at 4 , while the partial pressure of $\mathrm{Cl}_{2}+\mathrm{O}_{2}$ was varied from 0.38 to $1.00 \mathrm{~atm}$.

As indicated by figure 8 , the apparent reaction orders for $\mathrm{Cr}_{2} \mathrm{O}_{3}$ oxychlorination at $800^{\circ} \mathrm{C}$ with respect to $\mathrm{Cl}_{2}, \mathrm{O}_{2}$, and $\mathrm{Cl}_{2}+\mathrm{O}_{2}$ are respectively about $1.08,0.23$ and 1.29. One may note that the presence of oxygen enhances the reaction rate since ${ }^{\mathrm{n}} \mathrm{O}_{2}=0.23$. This observation agrees well with the oxychlorination of $\mathrm{Cr}_{2} \mathrm{O}_{3}$ (Eq. (3)) that consumes oxygen to generate chromium (VI) oxychloride $\left(\mathrm{CrO}_{2} \mathrm{Cl}_{2}\right)$.

As a contrast, the apparent reaction order with respect to $\mathrm{Cl}_{2}, \mathrm{O}_{2}$, and $\mathrm{Cl}_{2}+\mathrm{O}_{2}$ for $\mathrm{MgO}$ oxychlorination were $0.98,-0.37$ and 0.65 , indicating that the oxygen had a negative effect on the chlorination rate of $\mathrm{MgO}$. This result was expected and agrees with equation (2). On the other hand for both the studied cases $\left(\mathrm{Cr}_{2} \mathrm{O}_{3}\right.$ or $\left.\mathrm{MgO}\right)$, the global order is almost equal to the algebraic sum of the partial orders: ${ }^{\mathrm{n}}\left(\mathrm{Cl}_{2}+\mathrm{O}_{2}\right) \approx \mathrm{n}^{\mathrm{n}} \mathrm{Cl}_{2}+{ }^{\mathrm{n}} \mathrm{O}_{2}$.

\subsection{Determination of the apparent activation energy of reaction}

\subsubsection{Determination of $E_{a}$ of the reaction from isothermal treatment}

The apparent activation energy ' $\mathrm{E}_{\mathrm{a}}$ ' could be evaluated from Arrhenius equation:

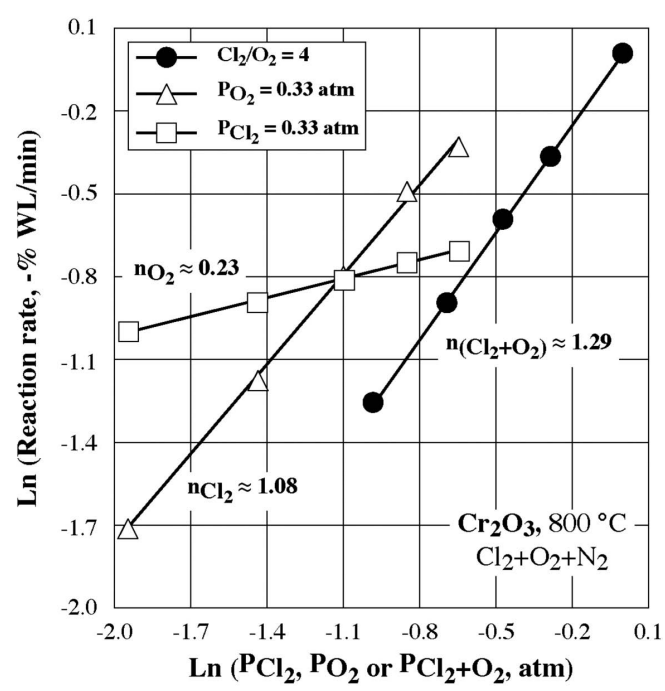

Figure 8. Evolution of the reaction rate of $\mathrm{Cr}_{2} \mathrm{O}_{3}$ oxychlorination at $800^{\circ} \mathrm{C}$ versus partial pressure of reactive gases.

Figura 8. Evolución de la tasa volatilizada en la reacción de oxicloración del $\mathrm{Cr}_{2} \mathrm{O}_{3}$ a $800^{\circ} \mathrm{C}$ frente a la presión parcial de los gases reaccionantes. 


$$
V=k * e^{\left(-E_{2} / R T\right)}
$$

or

$$
\operatorname{LnV}=\operatorname{LnK}-E_{d} / R T
$$

where $R$ is the gas constant, $T$ is the temperature in Kelvin, and $k$ is a constant.

To determine $\mathrm{E}_{\mathrm{a}}$, the solid is first heated at a predetermined temperature under nitrogen atmosphere, and when a steady state is reached, the gas mixture is introduced to react with the solid at constant temperature and the evolution of the reaction extent as a function of time is recorded. Therefore, the initial reaction rate for every tested temperature is determined. The value of $\mathrm{E}_{\mathrm{a}}$ is deduced from the slope of the straight line representing equation (6).

\subsubsection{Geometry of interface (shape factor)}

As the reaction of solid with chlorine takes place generally at interface of two phases, the geometry of this interface plays an important role to localize the reaction front and consequently affecting the the reaction progress. The mathematical formulations of the reaction progress (Eqs. (7) - (13)) are given for different shapes of particles. These formulations are designed as conversion functions of solid ' $g(X)^{\prime}$. The interpretations of these functions were published by Szekely J. et al. ${ }^{[11]}$. One may note that these formulations are valid when the overall reaction rate is affected by the slowest step.

Equation (7) is considered to describe a reaction controlled by the chemical reaction in the case of shrinking nonporous particles (with or without a solid porous product) and porous particles with unchanged overall size. It also applies for a mechanism affected by pore diffusion in the case of complete gasification of porous solids.

$$
\begin{gathered}
1-(1-X)^{1 / F p}=k t \\
X=k t \text { for } F p=1 \\
1-(1-X)^{1 / 2}=k t \text { for } F p=2 \\
1-(1-X)^{1 / 3}=k t \text { for } F p=3 \\
X^{2}=k t \text { for } F p=1 \\
X+(1-X) L n(1-X)=k t \text { for } F p=2 \\
1-3(1-X)^{1 / 3}+2(1-X)=k t \text { for } F p=3
\end{gathered}
$$

where

$k:$ constant, $\mathrm{t}:$ reaction time,

$X$ : extent of reaction (ratio of weight of the reacted fraction to initial weight),

Fp : particle shape factor (1,2, and 3 for infinite slabs, long cylinders, and for spheres).

Equations (11) through (13) are pertinent to pore diffusion control in reaction of porous solids or in nonporous solids with formation of a porous solid product.

The geometry of the solid particles combined with the value of the apparent activation energy permit to suggest the rate-controlling step of the chlorinesolid reactions. The following paragraphs describe several examples.

Figure 9 groups the data obtained during the isothermal carbochlorination of $\mathrm{Cr}_{2} \mathrm{O}_{3}$ between 500 and $900^{\circ} \mathrm{C}$ [2]. The apparent activation energy is $100 \pm 2 \mathrm{~kJ} / \mathrm{mol}$ (Fig. $9 \mathrm{a})$ ). This value tends to indicate that the overall rate of $\mathrm{Cr}_{2} \mathrm{O}_{3}$ carbochlorination in $\mathrm{Cl}_{2}+\mathrm{CO}$ is controlled by the chemical reaction. To check this hypothesis, the mathematical formulation of the experimental data was attempted using equations (7) through (13). The best result (Fig. 9 b) and c)) of data linearization, with a correlation coefficient of $\approx 0.998^{[10]}$, was obtained using equation (10). This supports the hypothesis that the carbochlorination reaction of $\mathrm{Cr}_{2} \mathrm{O}_{3}$ particles is controlled by a chemical reaction according to the shrinking sphere model described by equation (10).

\subsection{Chlorination kinetics of combined oxides}

The oxychlorination kinetics of chromite could be presented as a case study. The chromite presents a spinel structure including $\mathrm{Cr}, \mathrm{Fe}, \mathrm{Mg}$, and $\mathrm{Al}$ oxides. As mentioned in section 3, the chromite sample used had the following composition: $\left(\mathrm{Fe}_{0.30}^{2+}, \mathrm{Mg}_{0.70}\right)$ $\left(\mathrm{Cr}_{1.56}, \mathrm{Al}_{0.37}, \mathrm{Fe}_{0.07}^{3+}\right) \mathrm{O}_{4}$. This solid can also be formulated as: $30.9 \% \mathrm{FeCr}_{2} \mathrm{O}_{4}, 51.0 \% \mathrm{MgCr}_{2} \mathrm{O}_{4}$, $13.7 \% \mathrm{MgAl}_{2} \mathrm{O}_{4}$, and $4.4 \% \mathrm{Fe}_{3} \mathrm{O}_{4}$. The temperature effect on the oxychlorination of chromite was explored between 600 and $1,050^{\circ} \mathrm{C}^{[2 \mathrm{y} 6]}$. Results showed that the iron associated to chromium reacted with $\mathrm{Cl}_{2}+\mathrm{O}_{2}$ starting at $600{ }^{\circ} \mathrm{C}$. This reaction could be considered as that of the simple spinel $\mathrm{FeCr}_{2} \mathrm{O}_{4}$, while $\mathrm{MgCr}_{2} \mathrm{O}_{4}$ reacts at temperature higher than $900{ }^{\circ} \mathrm{C}$ and $\mathrm{MgAl}_{2} \mathrm{O}_{4}$ seems to be refractory to the oxychlorinating gas mixture up to $1,050^{\circ} \mathrm{C}$. Figure 10 a) represents the evolution of \% weight change versus time of the chromite sample during its reaction with $\mathrm{Cl}_{2}+\mathrm{O}_{2}$ between 925 and $1,050^{\circ} \mathrm{C}$. This figure 

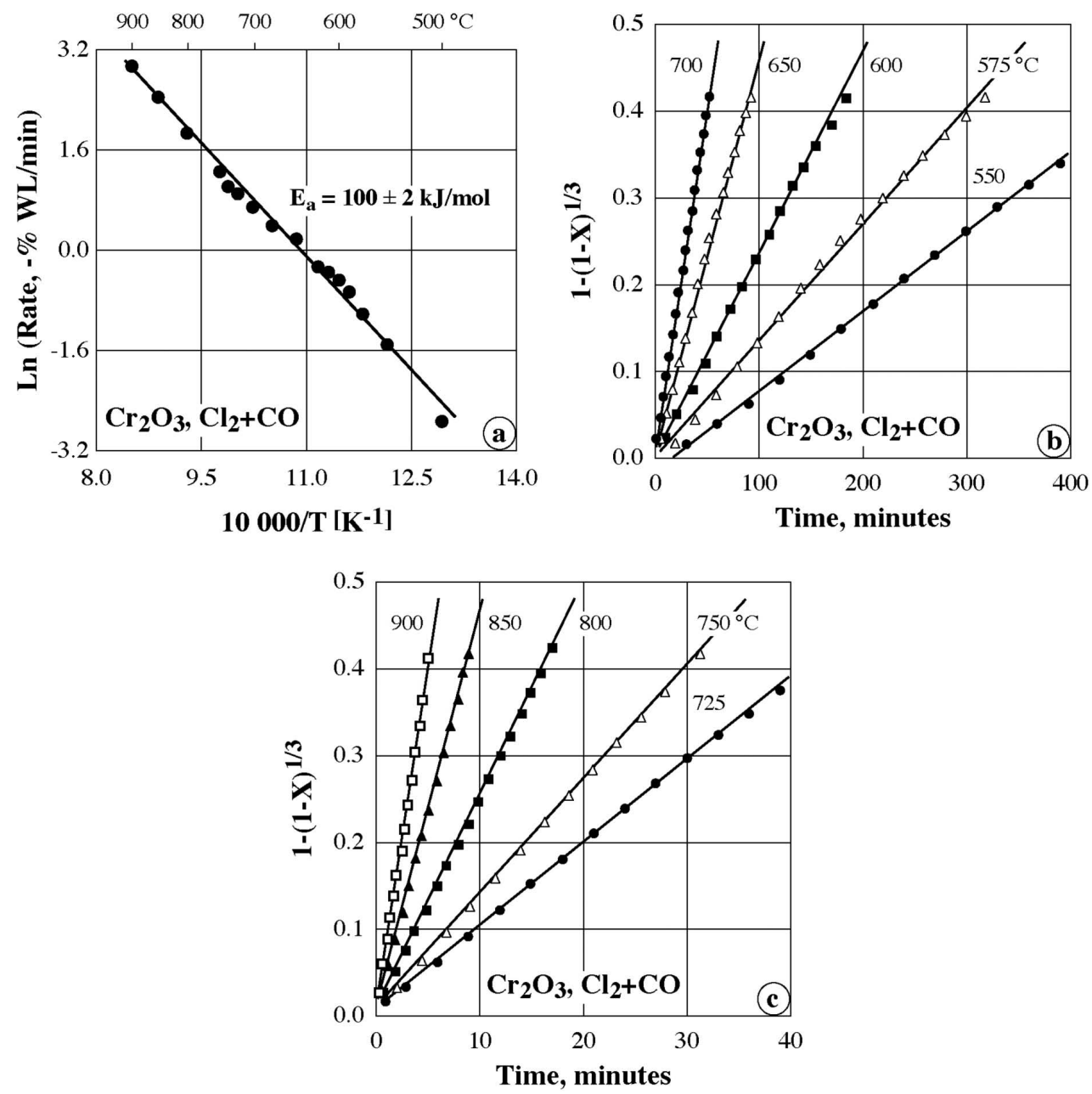

Figure 9. Plots of data obtained during isothermal carbochlorination of $\mathrm{Cr}_{2} \mathrm{O}_{3}$ in $\mathrm{Cl}_{2}+\mathrm{CO}$ : (a) Arrhenius diagram of carbochlorination and (b) and (c) Mathematical fitting of the experimental data using equation (10).

Figura 9. Gráficos de los datos obtenidos durante la carbocloración isoterma del $\mathrm{Cr}_{2} \mathrm{O}_{3}$ en $\mathrm{Cl}_{2}+\mathrm{CO}$ : (a) Diagrama de Arrhenius de carbocloración y (b) y (c) Ajustes matemáticos de los datos experimentales usando la ecuación (10).

shows the sharp change of the reaction rate of chromite at $\mathrm{X} \approx 0.35$. The first part of the weight loss corresponds essentially to the chlorination of $\mathrm{FeCr}_{2} \mathrm{O}_{4}+\mathrm{Fe}_{3} \mathrm{O}_{4}\left(\mathrm{~L}^{\mathrm{Ch}}\right)$ while the second part represents the reaction of $\mathrm{MgCr}_{2} \mathrm{O}_{4}$ with $\mathrm{Cl}_{2}+\mathrm{O}_{2}$.

The temperature coefficient of the reaction was determined using the Arrhenius formula. It was interesting to follow the evolution of apparent activation energy as a function of reaction extent. The variation of $\mathrm{E}_{\mathrm{a}}$ values versus the reaction extent is shown in figure $10 \mathrm{~b}$ ) for the temperatures range of 925 to $1050^{\circ} \mathrm{C}$.

Figure $10 \mathrm{~b}$ ) shows that the value of $\mathrm{E}_{\mathrm{a}}$, for $\mathrm{X}$ comprising between 0.05 and 0.30 , is lower than $60 \mathrm{~kJ} / \mathrm{mol}$. This is followed by a sharp increase of the apparent activation energy to $260 \mathrm{~kJ} / \mathrm{mol}$ for $\mathrm{X}>0.3$.
To get an insight of the reactions of chromite with $\mathrm{Cl}_{2}+\mathrm{O}_{2}$, a detailed study of the effects of temperature and partial pressures of gases $\left[{ }^{\mathrm{n}}\left(\mathrm{Cl}_{2}+\mathrm{O}_{2}\right) \approx{ }^{\mathrm{n}} \mathrm{Cl}_{2}+{ }^{\mathrm{n}} \mathrm{O}_{2}\right]$ on the oxychlorination of chromite and its simple oxides $\left(\mathrm{Cr}_{2} \mathrm{O}_{3}, \mathrm{Fe}_{2} \mathrm{O}_{3}\right.$, and $\left.\mathrm{MgO}\right)$ was performed. Results are summarized in figure 11 and in table I.

Although simple oxides are included in the spinel structure of chromite, the following hypothesis can be made:

- to chlorinate the chromite constituents ( $\mathrm{FeO} \cdot \mathrm{Cr}_{2} \mathrm{O}_{3}$ and/or $\mathrm{MgO} \cdot \mathrm{Cr}_{2} \mathrm{O}_{3}$ ) their individual oxides have to react with the chlorinating gas mixture,

- the global chlorination rate of chromite constituents depends of the slowest reaction rate of the individual oxide, 

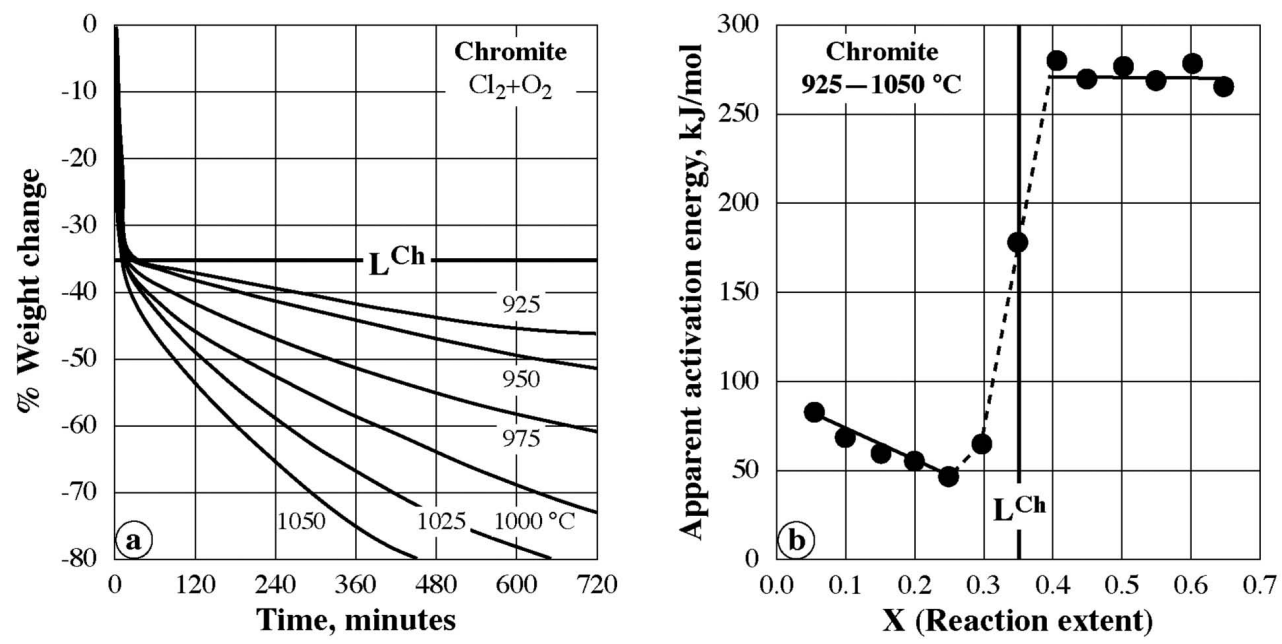

Figure 10. Oxychlorination of chromite between 925 and $1050{ }^{\circ} \mathrm{C}$ in $\mathrm{Cl}_{2}+\mathrm{O}_{2}$ atmosphere. (b) Shows the evolution of the apparent activation energy values as a function of the reaction extent calculated from the data of (a).

Figura 10. Evolución del \% de cambio de peso frente al tiempo de la oxicloración de la cromita por atmósferas de $\mathrm{Cl}_{2}+\mathrm{O}_{2}$. La figura (b) indica la evolución de los valores de la energía aparente de activación en función de la extensión de la reacción que se puede calcular a partir de los datos expresados en la figura (a).

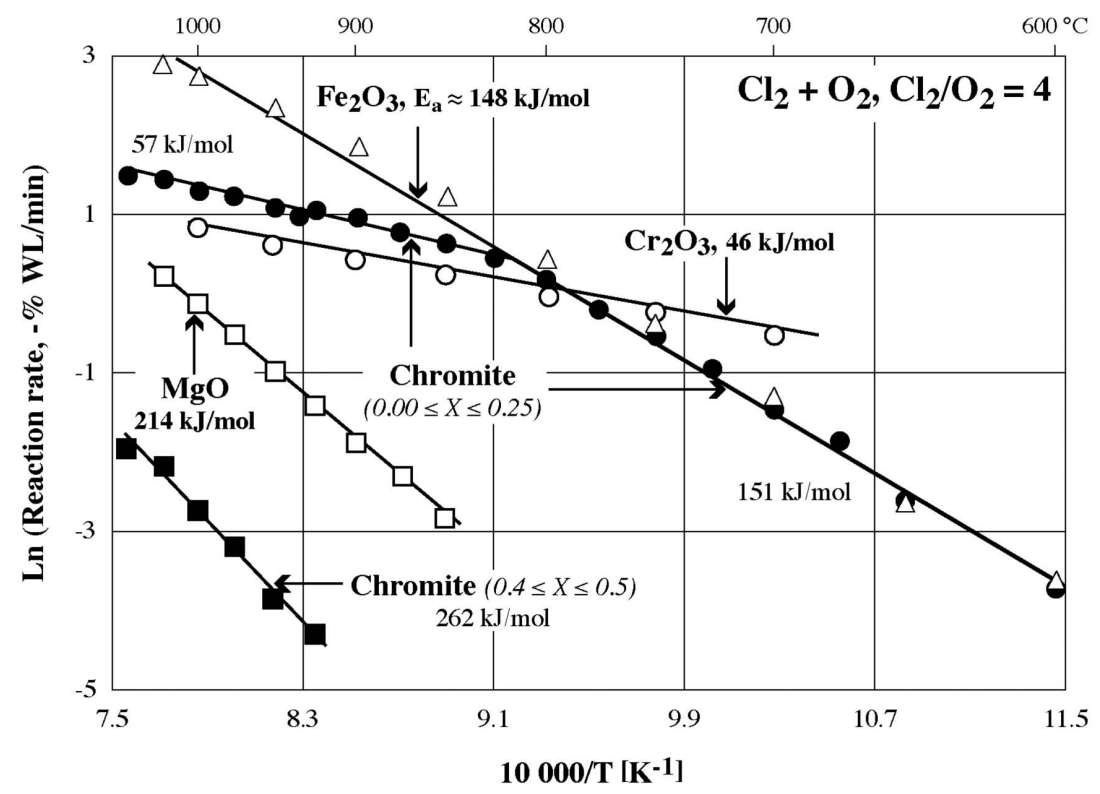

Figure 11. Arrhenius diagrams for the oxychlorination of chromite and its simple oxides in $\mathrm{Cl}_{2}+\mathrm{O}_{2}$.

Figura 11.- Diagramas de Arrhenius de la oxicloración de cromita y sus óxidos sencillos asociados en atmósfera. de $\mathrm{Cl}_{2}+\mathrm{O}_{2}$.

- the kinetics parameters of the chlorination of chromite constituents should have comparable values to those of chlorination of individual oxide having the slowest reaction rate.
Figure 11 shows that the oxychlorination of chromite for $\mathrm{X} \leq 0.25\left(\mathrm{FeCr}_{2} \mathrm{O}_{4}\right)$ is characterized by a value of $\mathrm{E}_{\mathrm{a}} \approx 151 \mathrm{~kJ} / \mathrm{mol}$ between 600 and $825^{\circ} \mathrm{C}$. A similar value is obtained for the oxychlorination of $\mathrm{Fe}_{2} \mathrm{O}_{3}$ 
SOME KINETICS ASPECTS OF CHLORINE-SOLIDS REACTIONS ALGUNOS ASPECTOS CINÉTICOS DE LAS REACCIONES DE SÓLIDOS CON CLORO

Table I. Comparison of reaction orders with respect to reactive gases of solids' oxychlorination.

Tabla I. Comparación de los órdenes de reacción respecto de los gases reactivos de oxicloración de sólidos.

\begin{tabular}{lccccc}
\hline Solids & & $\mathbf{T},{ }^{\circ} \mathbf{C}$ & ${ }^{n}\left(\mathbf{C l}_{2}+\mathbf{O}_{2}\right)$ & ${ }^{{ }^{n} C_{2}}$ & ${ }^{{ }^{n} \mathbf{O}_{2}}$ \\
\hline $\mathrm{Cr}_{2} \mathrm{O}_{3}$ & & 800 & 1.29 & 1.08 & 0.23 \\
\hline $\mathrm{Fe}_{2} \mathrm{O}_{3}$ & & 750 & 0.71 & 1.44 & -0.61 \\
& & 950 & 0.70 & 1.39 & -0.62 \\
\hline $\mathrm{MgO}$ & & 950 & 0.65 & 0.98 & -0.37 \\
\hline Chromite & $(0.0 \leq X \leq 0.25)$ & 750 & 0.94 & 1.24 & -0.30 \\
& $(0.0 \leq X \leq 0.1)$ & 1000 & 1.04 & 1.21 & -0.24 \\
& $(0.2 \leq X \leq 0.3)$ & & 1.23 & 1.03 & 0.16 \\
& $(0.4 \leq X \leq 0.5)$ & & 0.43 & 0.64 & -0.25 \\
\hline
\end{tabular}

$\left(\mathrm{E}_{\mathrm{a}} \approx 148 \mathrm{~kJ} / \mathrm{mol}\right)$. Moreover, the oxychlorination rates of $\mathrm{FeCr}_{2} \mathrm{O}_{4}$ and $\mathrm{Fe}_{2} \mathrm{O}_{3}$ are identical. In addition, the apparent reaction orders with respect to $\mathrm{Cl}_{2}+\mathrm{O}_{2}, \mathrm{Cl}_{2}$, and $\mathrm{O}_{2}$ for the oxychlorination of chromite and $\mathrm{Fe}_{2} \mathrm{O}_{3}$ have the same tendency (Table I). While the kinetics parameters of $\mathrm{Cr}_{2} \mathrm{O}_{3}$ oxychlorination are different from those obtained for the chromite (Fig. $11 \&$ Table I). These experimental results indicate that the oxychlorination rate of iron oxides governs the global rate of the $\mathrm{FeCr}_{2} \mathrm{O}_{4}$ reaction with $\mathrm{Cl}_{2}+\mathrm{O}_{2}$ for temperatures lower than $825^{\circ} \mathrm{C}$.

At temperature higher than $825^{\circ} \mathrm{C}$, the oxychlorination of chromite $(\mathrm{X} \leq 0.25)$ proceeds with a value of $\mathrm{E}_{\mathrm{a}} \approx 57 \mathrm{~kJ} / \mathrm{mol}$. This value and the reaction rate are fairly similar to those obtained for $\mathrm{Cr}_{2} \mathrm{O}_{3}$ oxychlorination $\left(\mathrm{E}_{\mathrm{a}} \approx 46 \mathrm{~kJ} / \mathrm{mol}\right)$. The positive value of $\mathrm{nO}_{2}$ for a determined reaction extent (Table I) reinforces the hypothesis that the oxychlorination rate of chromite $(\mathrm{X} \leq 0.30)$, at $\mathrm{T}>825^{\circ} \mathrm{C}$ is controlled, fully or partly, by the oxychlorination rate of $\mathrm{Cr}_{2} \mathrm{O}_{3}$.

The temperature coefficient of the chromite chlorination for $\mathrm{X}>0.4\left(\mathrm{MgO} \cdot \mathrm{Cr}_{2} \mathrm{O}_{3}\right)$ is about $262 \mathrm{~kJ} / \mathrm{mol}$ from 925 to $1050^{\circ} \mathrm{C}$. On the other hand, the values of $\mathrm{Ea}$ for $\mathrm{Cr}_{2} \mathrm{O}_{3}\left(\mathrm{E}_{\mathrm{a}} \approx 46 \mathrm{~kJ} / \mathrm{mol}\right)$ and $\mathrm{MgO}$ $\left(\mathrm{E}_{\mathrm{a}} \approx 214 \mathrm{~kJ} / \mathrm{mol}\right)$ oxychlorination as well as those of the apparent reaction orders (Table I) suggest that the oxychlorination rate of $\mathrm{MgO}$ controls the global rate of chromite oxychlorination for $\mathrm{X} \geq 0.4$ at 925-1,050 ${ }^{\circ} \mathrm{C}$.

This study shows that the oxychlorination of chromite proceeds in two stages characterized by different reactivities of chromite towards $\mathrm{Cl}_{2}+\mathrm{O}_{2}$ gaseous mixture. The first stage is the $\mathrm{FeCr}_{2} \mathrm{O}_{4}$ chlorination and the second one is that of $\mathrm{MgCr}_{2} \mathrm{O}_{4}$ chlorination. In both cases, the global reaction rate was affected by the slowest rate of oxychlorination of individual oxides $\left(\mathrm{Fe}_{2} \mathrm{O}_{3}, \mathrm{Cr}_{2} \mathrm{O}_{3}, \mathrm{MgO}\right)$. However, one should take into account the bond energy of simple constituents of chromite to confirm the above mentioned mechanism.

\subsection{Comparison of the $E_{a}$ derived from isothermal and non-isothermal conditions}

The following paragraphs describe the theoretical approach $^{[12]}$ for the determination of the activation energy of a gas-solid reaction from a single TGA using linear temperature rise (LTR).

The reaction rate of a gas-solid reaction could be expressed according to equatión (14):

$$
d X / d t=k f_{1}\left(p_{A}\right) f_{2}(X) f_{3}(d)
$$

where $X$ is the reaction extent, $p_{A}$ is the partial pressure of the reactive gas(es) and $d$ is the mean particle size.

The effects of partial pressure of the reactive gases, reaction extent and particle size on the reaction rate are described by $f_{1}\left(p_{A}\right), f_{2}(X)$ and $f_{3}(d)$, respectively.

The temperature effect on the reaction rate is given by Arrhenius law (equation (15), using the rate constant $k$ ):

$$
k=k_{0} \exp \left(-E_{d} / R T\right)
$$


Integration of Eq. 14 in isothermal conditions gives:

$$
\int_{0}^{X} d X / f_{2}(X) \equiv g(X)=\int_{0}^{t} k f_{1}\left(p_{A}\right) f_{3}(d) d t
$$

The conversion function of the solid $g(X)$ depends generally on the geometric change occurring in the solid as the reaction proceeds. The different types of $g(X)$ were summarized in equations (7)-(13).

If the temperature is raised linearly with respect to time the temperature evolution may be given by equation (17):

or

$$
T=\Phi t
$$

$$
d T=\Phi d t
$$

Substituting equations (15) and (17) in equation (14) and rearranging the resulting equation, it was obtained:

$$
\operatorname{Ln}\left[(d X / d T) g^{\prime}(X)\right]=\operatorname{Ln}\left[k_{0} f_{1}\left(p_{A}\right) f_{3}(d) / \Phi\right]-E_{d} / R T
$$

In the above equation, $g^{\prime}(X)$ is the derivative of $g(X)$ with respect to $X$. The activation energy can be determined from the slop of data fitted by equation (19) when the appropriate type of $g(X)$ is determined.

\subsubsection{Example of the $E_{a}$ evaluation from one TGA test using LTR.}

The determination of the temperature effect on the reaction of $\mathrm{MgO}$ with the gas mixture of $\mathrm{Cl}_{2}+\mathrm{O}_{2}$ $\left(\mathrm{Cl}_{2} / \mathrm{O}_{2}=4\right)$ is chosen as example. As the reactivity of $\mathrm{MgO}$ towards oxychlorinating gas mixture was relatively low $[2,9$ y 10$]$ the heating rate of the sample was about $1{ }^{\circ} \mathrm{C} / \mathrm{min}$. Figure 12 represents the obtained results concerning the oxychlorination of $\mathrm{MgO}$ from 575 to $1,025^{\circ} \mathrm{C}$. Magnesium oxide started to react with the oxychlorinating gas mixture at temperatures higher than $800^{\circ} \mathrm{C}$ and about $70 \%$ of the sample had reacted at $1,025^{\circ} \mathrm{C}$.

The oxychlorination reaction of $\mathrm{MgO}$ with $\mathrm{Cl}_{2}+\mathrm{O}_{2}\left(\mathrm{Cl}_{2} / \mathrm{O}_{2}=4\right)$ was also studied in isothermal conditions between 850 and $1,025^{\circ} \mathrm{C}^{[8-10]}$ in order to compare the results with those obtained using LTR method. Figure 13 traces the evolution of \% weight change of the sample as a function of time during isothermal oxychlorination of $\mathrm{MgO}$. The evolution of the reaction extent $(X \leq 0.7)$ as function of time for all isotherms was appropriately described by equation $(9)^{[8 \text { y } 19]}$. Figure 14 a) represents the Arrhenius diagram giving the evolution of the natural logarithm of the rate constant " $k$ " as a function of

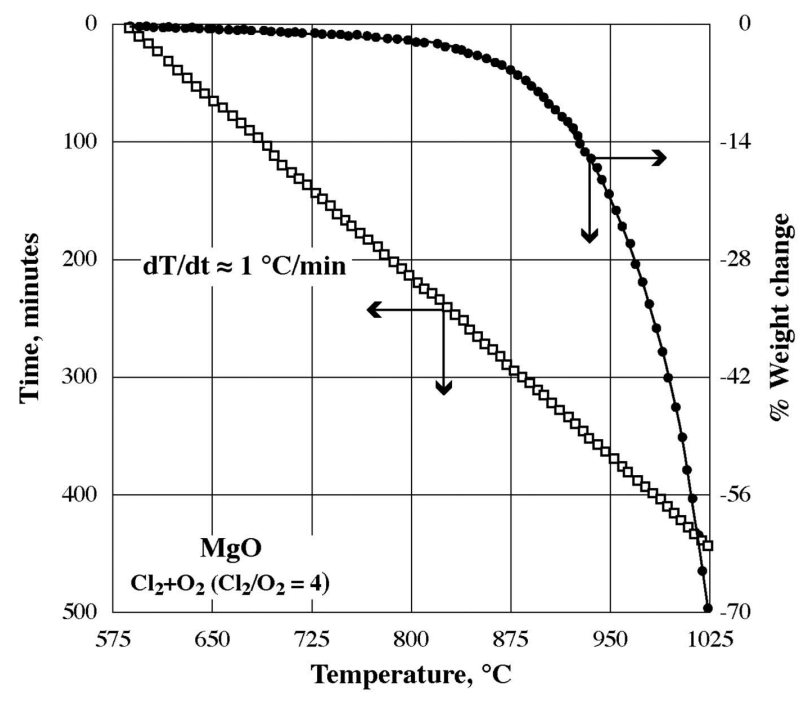

Figure 12. TGA of MgO oxychlorination using linear temperature raise.

Figura 12. Análisis termogravimétrico, ATG, de la oxicloración utilizando un aumento lineal de la temperatura.

the inverse of temperature. A value of $\mathrm{E}_{\mathrm{a}}$ about 213 $\mathrm{kJ} / \mathrm{mol}$ was deduced from the isothermal treatment of $\mathrm{MgO}$ in $\mathrm{Cl}_{2}+\mathrm{O}_{2}$.

Using equation (19), it is clear that the activation energy could be determined only after finding the appropriate form of $g(X)$. As for the isothermal tests, different models of the conversion function $g(X)$ were tried and the best non-isothermal data fitting was obtained by using equation (9). The data were plotted in figure $14 \mathrm{~b}$ ) using equation (19) for $\mathrm{X} \leq 0.70$. A value of $\mathrm{E}_{\mathrm{a}} \approx 215 \mathrm{~kJ} / \mathrm{mol}$ was deduced for the nonisothermal oxychlorination of $\mathrm{MgO}$ between $850^{\circ} \mathrm{C}$ and $1,025^{\circ} \mathrm{C}$. Figure 14 indicates that the activation energy values calculated using the two sets of data are almost identical. These results confirm the utility of non-isothermal measurements using LTR to determine the activation energy of gas-solid reactions.

\section{CONCLUSIONS}

The following general conclusions can be drawn from the kinetics studies of chlorination reactions of different materials through thermo-gravimetric measurements.

- The reactivity of different solids towards chlorinating gases varied widely e.g. the reaction $\mathrm{Cl}_{2}$ with $\mathrm{CuFeS}_{2}$ started at room 

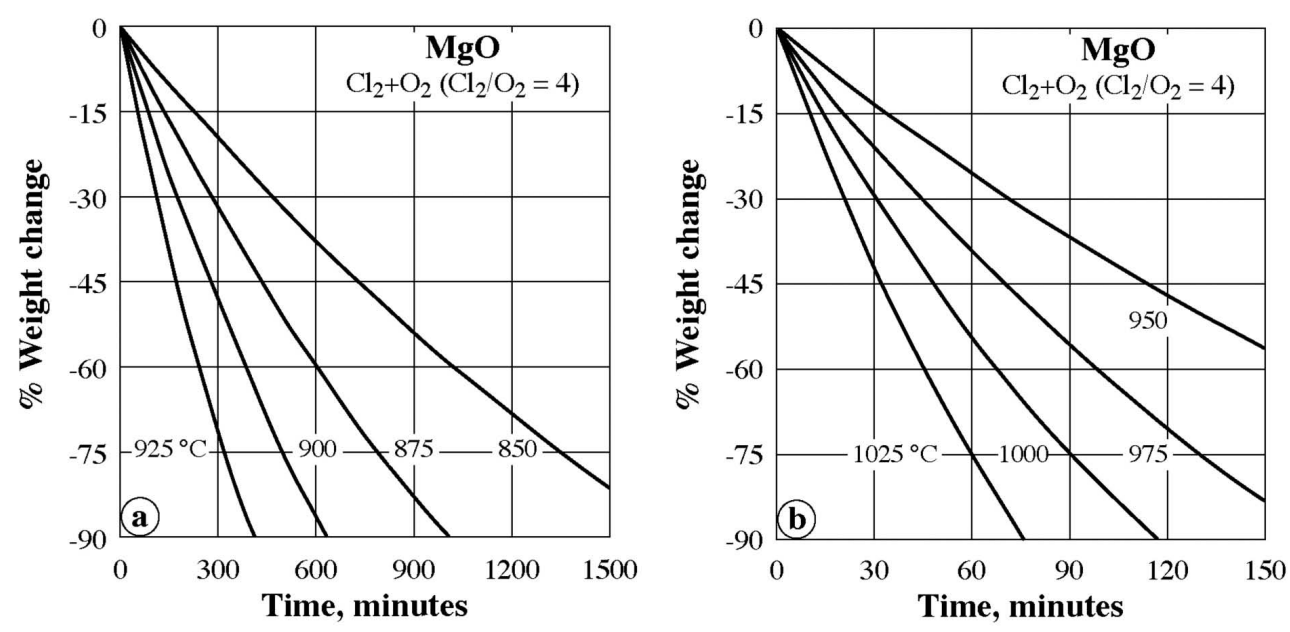

Figure 13. Evolution of the \% weight change as a function of the reaction time during isothermal oxychlorination of $\mathrm{MgO}$ oxychlorination for (a) $850-925^{\circ} \mathrm{C}$ and (b) $950-1,025^{\circ} \mathrm{C}$.

Figura 13. Evolución del cambio de peso como función del tiempo de reacción durante una oxicloración isotérmica del $\mathrm{MgO}$, para (a) en el intervalo $850-925^{\circ} \mathrm{C}$ y (b) en el intervalo $950-1.025^{\circ} \mathrm{C}$.
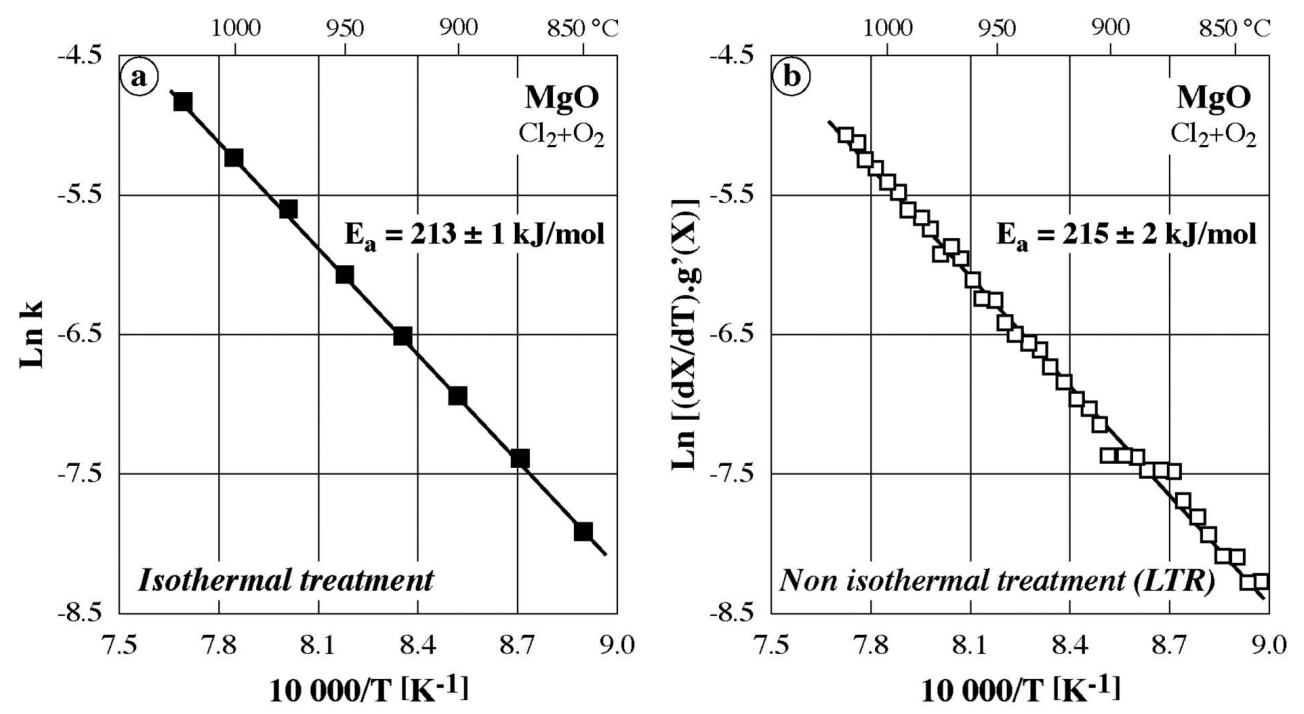

Figure 14. Arrhenius diagram of the $\mathrm{MgO}$ oxychlorination by $\mathrm{Cl}_{2}+\mathrm{O}_{2}$ for: (a) isothermal treatment and (b) non isothermal treatment.

Figura 14. Diagrama de Arrhenius de la oxicloración del $\mathrm{MgO}$ en atmósfera de $\mathrm{Cl}_{2}+\mathrm{O}_{2}$, para: (a) tratamiento isotérmico y (b) para tratamiento no isotérmico.

temperature while carbochlorination of $\mathrm{Cr}_{2} \mathrm{O}_{3}$ required a temperature $\geq 500^{\circ} \mathrm{C}$.

- The effect of external mass and heat transfer on the reaction rate could be minimized by choosing adequate gas velocities.

- The apparent reaction orders with respect to reactive gases $\left(\mathrm{Cl}_{2}, \mathrm{O}_{2}, \mathrm{CO}\right)$, obtained experimentally, were fractions, either positive or negative numbers. Although they differ from stoichiometric coefficients of the reaction, their positive or negative value depends on the considered chemical reactions. The apparent reaction order with respect to $\mathrm{O}_{2}$ is 0.23 for $\mathrm{Cr}_{2} \mathrm{O}_{3}$ oxychlorination, while that of $\mathrm{MgO}$ oxychlorination ${ }^{\mathrm{n}} \mathrm{O}_{2} \approx-0.37$. The oxychlorination reactions of $\mathrm{MgO}$ and $\mathrm{Cr}_{2} \mathrm{O}_{3}$ 
with $\mathrm{Cl}_{2}+\mathrm{O}_{2}$ explain this difference concerning the oxygen role in the two reactions.

- The value of $\mathrm{E}_{\mathrm{a}}$ depends on the type of solid, the nature of the chlorinating gas mixture $\left(\mathrm{Cl}_{2}, \mathrm{Cl}_{2}+\mathrm{O}_{2}, \mathrm{Cl}_{2}+\mathrm{CO}\right)$, the studied temperature range, the physical state of the reaction products, etc

- The isothermal and the linear temperature raise techniques gave essentially similar kinetic parameters. Further, from the formulation of the reaction interface geometry, the rate controlling step could be predicted accurately.

This study thus demonstrated that, simple thermogravimetric measurements can be utilized for measurement of complex reaction kinetics involving gas - solid reactions such as chlorination of variety of solid samples with number of reactive gases compositions. The obtained kinetics information can be used for process optimization involving beneficiation of lean ores and extraction of several valuable metals from their oxide or sulfide ores, which are otherwise difficult by traditional chemical beneficiation and/or extraction methods.

\section{REFERENCES}

[1] Proc. 32nd Ann. Hydrometallurgy Meet. and Int. Conf. Practice and Theory of Chloride/Metal
Interaction. Vol. I and II. Eds. E. Peek and G. van Weert, Pub. Canadian Institute of Mining, Metallurgy and Petroleum, Montreal, Canada, 2002.

[2] N. Kanari, Ph.D. Thesis, Institut National Polytechnique de Lorraine, France. 1995.

[3] N. Kanari, E. Allain, N. Menad and I. Gaballah, Metall Mater Trans B 30B (1999) 567-576.

[4] N. Kanari, I. Gaballah and E. Allain, Thermochim. Acta 373 (2001) 75-93.

[5] N. Kanari, E. Allain and I. Gaballah, Metall. Mater. Trans. B 30 (1999) 577-587.

[6] N. Kanari, I. Gaballah and E. Allain, Thermochim. Acta 371 (2001) 143-154.

[7] N. Kanari, I. Gaballah and E. Allain, Thermochim. Acta 371 (2001) 75-86.

[8] N. Kanari, I. Gaballah and E. Allain, Metall. Mater. Trans. B 30 (1999) 1009-1015.

[9] N. Kanari, E. Allain and I. Gaballah, Thermochim. Acta 351 (2000) 131-137.

[10] N. Kanari, Habilitation Diploma, Institut National Polytechnique de Lorraine, France, 2000.

[11] J. Szekely, J. W. Evans and H. Y. Sohn, GasSolid Reactions, Academic Press, New York, USA, 1976, pp. 68-70, 73-88, 109-131 and 232235.

[12] P.C. Chaubal and H.Y. Sohn, Metall. Mater. Trans. B 17 (1986) 51-60. 